IZA DP No. 5898

Parental Divorce and Generalized Trust

Tarja K. Viitanen

August 2011

Forschungsinstitut zur Zukunft der Arbeit Institute for the Study of Labor 


\title{
Parental Divorce and Generalized Trust
}

\author{
Tarja K. Viitanen \\ University of Otago \\ and IZA
}

\section{Discussion Paper No. 5898 \\ August 2011}

\author{
IZA \\ P.O. Box 7240 \\ 53072 Bonn \\ Germany \\ Phone: +49-228-3894-0 \\ Fax: +49-228-3894-180 \\ E-mail: iza@iza.org
}

Any opinions expressed here are those of the author(s) and not those of IZA. Research published in this series may include views on policy, but the institute itself takes no institutional policy positions.

The Institute for the Study of Labor (IZA) in Bonn is a local and virtual international research center and a place of communication between science, politics and business. IZA is an independent nonprofit organization supported by Deutsche Post Foundation. The center is associated with the University of Bonn and offers a stimulating research environment through its international network, workshops and conferences, data service, project support, research visits and doctoral program. IZA engages in (i) original and internationally competitive research in all fields of labor economics, (ii) development of policy concepts, and (iii) dissemination of research results and concepts to the interested public.

IZA Discussion Papers often represent preliminary work and are circulated to encourage discussion. Citation of such a paper should account for its provisional character. A revised version may be available directly from the author. 
IZA Discussion Paper No. 5898

August 2011

\section{ABSTRACT}

\section{Parental Divorce and Generalized Trust}

This paper examines the effect of parental divorce during childhood on generalized trust later on in life using Australian HILDA panel data. The dependent variable is composed of answers to the statement: "Generally speaking, most people can be trusted". The main explanatory variables include the occurrence of parental divorce for the whole sample and the age at which parents divorced for the sub-sample. The analysis is conducted using random effects ordered probit, correlated random effects ordered probit and instrumental variables ordered probit models. The results indicate that the level of generalized trust is significantly affected by parental divorce for both men and women. This main result is very robust to alternative specifications. Furthermore, there is a marginally significant effect on the expressed level of generalized trust due to age at which parents divorced for women, but not men.

JEL Classification: $\quad \mathrm{J} 12, \mathrm{J13}, \mathrm{H} 8, \mathrm{Z} 13$

Keywords: parental divorce, generalized trust, HILDA, random effects ordered probit, instrumental variables ordered probit

Corresponding author:

Tarja K. Viitanen

Department of Economics

University of Otago

Dunedin

New Zealand

E-mail: tarja.viitanen@otago.ac.nz

\footnotetext{
* I would like to thank Arnaud Chevalier and an anonymous referee for comments on earlier drafts of the paper.
} 


\section{Introduction}

At individual level, parental divorce is associated with lower levels of trust in their parents and future intimate partners (Franklin et al., 1990; King, 2002). This paper examines whether parental divorce has wider societal impacts, specifically whether it can affect generalized trust. Social capital including trust is found to have a significant economic payoff (Knack and Keefer, 1997; La Porta et al., 1997; Berggren, 2006; Bjornskov 2006, Stevenson and Wolfers, 2011). Although the effect of divorce has been estimated for outcomes of economic interest, for example, education, marriage and divorce propensity, and family incomes (Lang \& Zagorski, 2001; Corak, 2001; Gruber, 2004; Gonzalez and Viitanen, 2008), the effect has not previously been estimated for generalized trust.

This paper analyses the effect of parental divorce during childhood on generalized trust later on in life using Australian HILDA panel data. The analysis is conducted using random effects ordered probit, correlated random effects ordered probit and instrumental variables ordered probit model. The analysis uses law changes as well as parental background variables as instruments to arrive at a causal estimate of the effect of parental divorce on generalized trust. The dependent variable is composed of answers to the statement: "Generally speaking, most people can be trusted". The main explanatory variables include the occurrence of parental divorce for the whole sample and the age at which parents divorced for the subsample.

The results show that both men and women with divorced parents are in general significantly less likely to express trust in other people. The results are significant and negative across different model specifications. Further analysis examining the effect of the age of the child when parental divorce took place indicates a marginally significant effect of age at parental divorce on generalized trust for women only. 


\section{Data and econometric method}

This analysis is based on the Household, Income and Labour Dynamics in Australia (HILDA) Survey, which is a nationally-representative Australian household-based panel survey that has been conducted since 2001 .

The primary outcome measure used in this analysis is a 7-point Likert scale answer to question "To what extent do you agree or disagree with the following statements? Please indicate, by crossing one box on each line, how strongly you agree or disagree with each. a) Generally speaking, most people can be trusted", where the scale runs from 1 (Strongly Disagree) to 7 (Strongly Agree). This outcome measure is part of the Self-Completion Questionnaire, which is not part of the face-to-face interview. Furthermore, this variable is only available in waves 5,6 and 8 of the survey.

Of the initial Hilda sample for waves 1-9 (160,084 observations), 52,066 individuals participated in waves 5,6 , and/or 8 . The minimum age of the sample individual is restricted to 15 since this is the age when Self-Completion Questionnaire is required to be completed; this reduces the sample size to 40,839 observations. There are 6,889 missing values for trust data and a further 6,457 missing values for the parental divorce data ${ }^{1}$. This reduces the sample size to 27,493. Further 6 observations are not used due to missing socio-economic status variable. There are missing values for number of siblings (665 observations) and the oldest child (590 observations) dummy, instead of dropping these observations a dummy for missing cells is included in all regressions and the variable is recoded accordingly. In the end we have a sample size of 27,482 observations. Descriptive statistics for both, the male $(\mathrm{N}=12,869)$ and female $(\mathrm{N}=14,613)$ subsamples are provided in Table 1.

\footnotetext{
${ }^{1}$ Spearman rank-correlation coefficient between missing response for the generalized trust question and parental divorce is insignificant; the correlation coefficient between missing parental divorce variable and generalized trust is -0.08 and significant at $1 \%$ level. Although the parental divorce may not be missing at random, this is likely to lead to an underestimate of the true effect of parental divorce on generalized trust.
} 
Alesina and LaFerrara (2000) outline the possible hypotheses of the determinants of trust: 1) moral or cultural attitude, 2) trust based on past experience, 3) trusting people who are more similar to oneself, 4) trusting people with whom they have known longer and 5) legal institutions. The control variables in this analysis control for as many of the other determinants of trust as the data allows; Table 1 summarizes these variables for the sample.

\section{[Table 1 about here]}

Approximately $10 \%$ of the sample has experienced parental divorce; $10 \%$ of the divorces occurred before the child turned 7 years of age and $50 \%$ occurred before they turned 16. A typical respondent is in their mid-40s with diploma/certificate level education for men and year 11 or below education level for women. About a third of the sample have their own children. Stability measures the number of years at the current address, which is 10 years on average for the sample.

Deciles 1-10 refer to the SEIFA 2001 index of relative socio-economic advantage/disadvantage, where 1 is the lowest and 10 is the highest decile. Out of the health conditions, the most common one is limited use of feet/legs with about $5 \%$ of the sample. Second most common ailment is nervous or emotional condition with $2.4 \%$ of men and $3.5 \%$ of women of the sample suffering from these health conditions. Indigenous refers to aboriginal or Torres Strait origin. $27 \%$ of the sample individuals have both parents with an immigrant background.

As discussed previously, the main dependent variable is a 7-point Likert scale answer to the question "To what extent to you agree or disagree with the following statements? Please indicate, by crossing one box on each line, how strongly you agree or disagree with each. a) Generally speaking, most people can be trusted", where the scale runs from 1 (Strongly Disagree) to 7 (Strongly Agree). An OLS analysis treats Likert-scale variables as 
cardinal. However, it is likely that respondents do not treat an attitude level 4 as four times as trusting as those reporting response 1 . Therefore the econometric method takes into account the ordinal nature of the dependent variable by using an ordinal response model.

The central idea of the ordered response model is that there is a latent continuous metric $y^{*}$ underlying the ordinal responses observed by the researcher. The latent variable specification of the estimated random effects ordered probit model can be written as:

$$
y_{i t}^{*}=\beta x_{i t}+\alpha_{i}+\varepsilon_{i t}
$$

where $x_{i t}$ is a set of observed variables that may be associated with the generalized trust indicator, $\alpha_{i}$ is an individual-specific, time-invariant random component capturing individual-specific heterogeneity and $\varepsilon_{i t}$ is assumed to be a random error term. The random error is assumed to be strictly exogenous, that is uncorrelated with $x_{i t}$.

The observed generalized trust variable is assumed to be related to the latent generalized trust variable $y^{*}$ in the following way:

$$
y_{i t}=j \quad \text { if } \quad \mu_{j-1}<y_{i t}^{*}<\mu_{j} \quad, j=1, \ldots, J
$$

where $J$ is the number of response categories. An ordered probit model estimates an underlying score as a linear function of the control variables and a set of cutpoints or threshold parameters $\mu_{j}$ that are empirically estimated. Equation (2) states that if $y_{i t}^{*}$ is between $\mu_{j-1}$ and $\mu_{j}$, the response to the question on generalized trust is equal to $j\left(y_{i t}=j\right)$. The ordered probit models are estimated using ordered probit available in Stata (Release 11, Stata Corporation) and random effects ordered probit estimator, which is a user-written program introduced to Stata by Frechette (2001a, 2001b). The random effects ordered probit model is estimated using maximum likelihood estimation with the likelihood for each unit approximated by Gauss-Hermite quadrature (see Butler and Moffitt, 1982 for more details). 
The assumption that the random error term is uncorrelated with $x_{i t}$ is restrictive and if it is not satisfied, the estimates may be inconsistent. Correlated random effects ordered probit estimation allows for the possibility that the observed regressors may be correlated with the individual effect (Mundlak, 1978, Chamberlain, 1984, Wooldridge, 2009). In practice the individual effect is parameterized allowing correlation between the individual effects and the means of the regressors:

$$
\alpha_{i}=\alpha_{0}+\alpha_{1} \bar{x}_{i}+u_{i}
$$

where $\bar{x}_{i}$ is the average of the observations on the exogenous variables over the sample period and $u_{i}$ are independent of the $x$ variables.

One could argue that parental divorce is endogenous to one's level of generalised trust, for example, if people with low levels of trust are 1) more likely to divorce and 2) trust is transmitted between generations. The ideal instrument would be parents' level of generalised trust, however, since this is not available in the data, other parental background variables are used to proxy this. Parental background variables that are available to be used as instruments include: 1) dummy for whether father was unemployed when the respondent was age 14,2 ) dummy for whether either one of the parents emigrated to Australia from a country that had adopted no fault divorce before Australia and 3) dummy for the respondent still living at home. Sayer et al. (2011) find that the likelihood of divorce increases when the husband is unemployed. This justifies the first parental background instrument assuming that paternal unemployment is not a significant predictor of one's generalised trust. The second parental background instrument captures the immigrant parent's cultural background and 
attitudes to divorce, while the last parental background instrument captures the level of family unity ${ }^{2}$.

A second set of instruments includes divorce laws, specifically the incidence of easier divorce that took place in the 1970's. The Matrimonial Causes Act of 1959 introduced the first uniform divorce laws across the Australian states and territories, however, state and territory laws continued to apply to cases where spouses were seeking orders relating to their children or their property (Family Court of Australia, 2009). The Matrimonial Causes Act conferred the Federal Jurisdiction in divorce on the states. The Matrimonial Causes Act of 1959 came into force in 1961 (Morris, 1962). This information is used to create an instrument which takes the value 1 prior to 1961.

[Figure 1 about here]

The Family Law Act 1975 replaced the Matrimonial Causes Act 1959 and introduced no-fault divorce to Australia, which came into force on 5 January 1976. This law superseded state and territory laws regarding "guardianship, custody, access and maintenance of children of a marriage" (Family Court of Australia, 2009). Figure 1 indicates that the 1976 law change specifically had a large effect on the divorce rate in Australia. Divorce laws have been previously used to identify a causal outcome of parental divorce on later child outcomes by, for example, Gruber (2004) and Gonzales and Viitanen (2008). The estimation uses pooled instrumental variables ordered probit, which is a user-written program in Stata developed by Roodman (2008, 2009).

The models are estimated separately for men and women. This is to ensure that the variance of the residual is not constrained to be the same in the two groups as would be the case with pooled data ${ }^{3}$.

\footnotetext{
${ }^{2}$ It is worth noting that the age range of the individuals for whom this variable is 1 varies from 15 to 61.
} 
3. Results of the impact of parental divorce on generalized trust

3.1 Effect of the incidence of parental divorce on generalized trust

This section examines the effect of parental divorce on generalized trust later in life. Table 2 presents the results of the effect of parental divorce on generalized trust for women using ordered probit, random effects ordered probit and correlated random effects ordered probit. The tables report the probit coefficients ${ }^{4}$. Estimates of the six threshold parameters $(\mu)$ are significant at the $1 \%$ level but are not reported due to space considerations. All of the regressions also include dummies for missing values for education, number of siblings and being oldest child variables; these are not significant in any of the models and hence are not reported in the tables of results. Year dummies to control for the time-dimension of the panel data were included in the model but were found not to affect the inferences and hence were not included in the final specifications.

The main independent variable looking at whether one's parents were divorced is negative and statistically significant across all specifications. This implies that women with divorced parents are in general less likely to express trust in other people.

[Table 2 about here]

Education level has a positive effect on the level of generalized trust with those with higher levels of education more likely to have a high level of generalized trust. Interestingly, the number of own siblings is negatively associated with one's level of trust, while being the oldest is positively related to the level of generalized trust. While the education and number

\footnotetext{
${ }^{3}$ The results estimated using pooled data with intercept shifts and both intercept and slope shifts are available from the author upon request.

${ }^{4}$ Average marginal effects or marginal effects at the mean are not straightforward to calculate since the marginal effect depends on the realisation of the random effect and these are not calculated by the estimation procedure.
} 
of siblings effects become insignificant in the correlated random effects model, the variable oldest child remains significant across all specifications.

The effect of a long-term health condition is investigated by including dummy variables for 1) a nervous/emotional condition, 2) any disfigurement/deformity, 3) limited use of feet or legs, and 4) a mental illness. All of these are significant and negative in model (1), while disfigurement/deformity loses significance in the random effects ordered probit model. All of the health condition variables become insignificant in the correlated random effects specification, some of which may be due to larger standard errors.

The results for men are reported in Table 3. The main independent variable looking at whether one's parents were divorced is negative and significant across all the specifications implying that men with divorced parents are less likely to trust other people in general.

\section{[Table 3 about here]}

For men only the higher education variables are significantly different from zero, unlike for women for whom the results were significant and increasing with the level of education. Interestingly the random effects ordered probit indicates that having own children is associated with higher levels of one's generalized trust. Nervous or emotional health condition is the only one that is significantly associated with lower level of generalized trust across all specifications for men.

Important from a policy perspective is the finding that having immigrant parents (either one or both depending on specification) is marginally associated with lower levels of generalized trust. This could indicate some problems assimilating to the Australian society and might deserve more detailed research. 
Likelihood ratio statistics were used to compare the random effects ordered probit model with the simple pooled ordered probit model. Specifically the null hypothesis of the test is $\alpha_{i}=0$. When $\alpha_{i}$ is not zero the panel-level variance component is important and the random effects ordered probit is a significant improvement on the simple pooled ordered probit. Results for both men and women indicate that the $\alpha_{i}$ is important.

Further random effects ordered probit models are run for the following dependent variables that can be considered similar in nature to the generalized trust question used as a dependent variable thus far. These variables include 7-point Likert scale composed of slightly/moderately/strongly agreeing or disagreeing (with 4 being neutral) with the following statements: 1) "Most people you meet make agreements honestly", 2) "Most people would try to take advantage of you if they got a chance" and 3) "Neighborhood: People in this neighborhood can be trusted". The parental divorce dummy is not significant for either gender in any of these regressions. Hence the generalized trust question appears to capture the individual's trust in general rather than any grievances one may feel due to previous bad experiences regarding specific past agreements.

\subsection{Instrumental variables results}

Table 4 reports instrumental variables ordered probit estimation results. There are separate regressions using the whole set of instruments (pre-uniform, no fault, easy divorce background, dad unemployed at 14, still at home) in columns 1 and 3 for women and men respectively and the subset of instruments for law changes alone (pre-uniform, no fault) in columns 2 and 4 for women and men respectively. The instruments are discussed in some detail in section 2 .

The instrumental variables results are very similar to the previously presented results of the effect of parental divorce on generalized trust. The results for women are smaller in 
magnitude compared to the previous random effects specifications, however, they are negative and highly significant. For men, the negative and highly significant results are of similar magnitude compared to the previous specifications presented in Table 3 .

[Table 4 about here]

Similar to the previous specifications, higher educated men and women are more likely to express agreement to the generalized trust question with the result being stronger for women with postgraduate qualifications. The length of time at current address (stability) and being the oldest child have positive significant effect on one's level of trust while an immigrant mother has a negative effect on one's expression of trust in other people in general. The health conditions have a strong negative effect on trust and while all the different health conditions are significant for women, for men only "nervous/emotional condition" and "limited use of feet/legs" are significantly different from zero.

Overall the results of the main research question of interest in this paper, the effect of parental divorce on one's own level of generalized trust are significant and negative and highly robust across the different model specifications including random effects models and instrumental variables estimation.

\subsection{Effect of age at parental divorce}

This section examines whether the age at which parents divorced affects ones level of generalized trust. The analysis is restricted to individuals whose parents have divorced; this reduces the sample size to 1,521 women and 1,360 men for the full sample (the results are not reported) and to 667 women and 563 men for the sub-sample excluding the pre-uniform law era (Table 5). The results are never significant for the full sample nor using the random effects ordered probit or the correlated random effects ordered probit and are not reported, 
however, the results for post-1961 using the instrumental variables estimation are reported in Table 5. Due to this sample restriction, it is no longer possible to use the pre-uniform instrument.

\section{[Table 5 about here]}

Table 5 reports instrumental variables ordered probit with the full set of instruments in columns 1 and 3 for women and men respectively and the no fault law change instrument in columns 2 and 4 . The estimates are only reported for the main variables of interest that is dummies for whether parental divorce happened when the child was 0-4 years old, 5-12 years old, 13-17 years old, or 18 or older. Alternative specifications including linear, quadratic and cubic terms of age at parental divorce were never significant for either men or women.

The coefficient estimate for women is large and negative for those women who experienced parental divorce between ages 0 to 4 . However, the result is only marginally significant. This result is interesting in itself and deserves further investigation. Unfortunately the current data does not grant any further analysis on the potential pathways from parental divorce to one's trust since there is not information on for example whether the mother remarried or stayed single, or on household income during childhood. Single parenthood, low income while growing up or a new stepfather are just a few potential aspects to investigate in this respect.

\section{Conclusions}

This paper analyses the effect of parental divorce during childhood on generalized trust later on in life using Australian HILDA panel data. The analysis is conducted using ordered probit, random effects ordered probit and correlated random effects probit. The dependent variable is a 7-point Likert scale answer agreeing or disagreeing with the statement: "Generally speaking, most people can be trusted". The main explanatory variable is the 
occurrence of parental divorce. The effect of parental divorce on the level of generalized trust is estimated using random effects models as well as instrumental variables models. Further analysis is conducted examining the effect at which parents divorced for the level of generalized trust.

The results indicate that the level of generalized trust is significantly affected by parental divorce with both men and women who have experienced parental divorce expressing significantly lower levels of generalized trust for the main sample. The results remain strong across the different model specifications.

Throughout the different specifications, there is a marginally significant negative effect of having one or both parents being immigrants. This is an interesting effect in itself and deserves further research.

Further analysis examining the effect of the age of the child when parental divorce took place shows marginally significant effects for women only, implying that parental divorce for a pre-school age girl has a negative effect on later generalized trust. 
References

Alesina, A. and La Ferrara, E. (2000) "The determinants of trust", NBER Working Paper No. 7621.

Alesina, A. and La Ferrara, E. (2002) "Who trusts others?”, Journal of Public Economics, 85(2): 207-234.

Berggren, N. and Jordahl, H. (2006) "Free to Trust: Economic Freedom and Social Capital", Kyklos, 59(2): 141-169.

Bjornskov, C. (2006) "Determinants of generalized trust: a cross-country comparison", Public Choice, 130: 1-21.

Bjornskov, C. (2006) "The multiple facets of social capital”, European Journal of Political Economy, 22(1): 22-40.

Butler, J.S. and Moffitt, R. (1982) “A computationally efficient quadrature procedure for the one-factor multinomial probit model", Econometrica, 50: 761-764.

Chamberlain, G. (1984) Panel data. Chapter 22, pp. 1247-1318. North Holland, Amsterdam. in handbook of Econometrics, Vol. 1, edited by Griliches, Z. And Intriligator, M.

Corak, M. (2001) "Death and divorce: the long-term consequences of parental loss on adolescents", Journal of Labor Economics, 19(3): 682-715.

Dolan, P., Peasgood, T. and White, M. (2008) "Do we really know what makes us happy? A review of the economic literature on the factors associated with subjective well-being", Journal of Economic Psychology, 29: 94-122.

Family Court of Australia (2009) http://www.familycourt.gov.au/wps/wcm/connect /FCOA/home/about/For_Students/FCOA_Student_AFL, accessed November 242009.

Franklin, K. M., Janoff-Bulman, R. and Roberts, J. E. (1990) "Long-term impact of parental divorce on optimism and trust: changes in general assumptions or narrow beliefs", Journal of Personality and Social Psychology, 59(4): 743-755.

Frechette, G. (2001a) “Sg158: random-effects ordered probit”, Stata Technical Bulletin, 59: 23-27 Reprints 10, 261-266.

Frechette, G. (2001b) "Sg158.1: update to random-effects ordered probit", Stata Technical Bulletin 61: 12 Reprints 10, 266-267.

Gonzalez, L. and Viitanen, T.K. (2008) "The Long Term Effects of Legalizing Divorce on Children”, IZA Discussion Paper No. 3789. 
Gruber, J. (2004) "Is Making Divorce Easier Bad for Children? The Long-Run Implications of Unilateral Divorce”, Journal of Labor Economics, 22(4): 799-833.

Lang, K. and Zagorsky, J.L. (2001) “Does growing up with a parent absent really hurt?", Journal of Human Resources, 36(2): 253-273.

La Porta R., Lopez de Silanes, F. Shleifer, A. and Vishny, R. (1997) "Trust in large organizations", American Economic Review, Papers and Proceedings, 87(2): 333-338.

King, V. (2002) "Parental Divorce and Interpersonal Trust in Adult Offspring", Journal of Marriage and Family, 64(3): 642-656

Knack, S. and Keefer, P. (1997) "Does social capital have an economic payoff?", Quarterly Journal of Economics, 112: 1251-1273.

Morris, J.H.C. (1962) “The Australian Matrimonial Causes Act, 1959”, The International and Comparative Law Quarterly, 11(3): 641-650.

Mundlak, Y. (1978) "On the pooling of time-series and cross-section data", Econometrica, 46(1): 69-85.

Roodman, D. (2008) “cmp: Stata module to implement conditional (recursive) mixed process estimator", http://ideas.repec.org/c/boc/bocode/s456882.html.

Roodman, D. (2009) "Estimating fully observed recursive mixed-process models with cmp", Working Paper 168. Center for Global Development. Washington, DC.

Rowthorn, R. (1999) "Marriage and trust: some lessons from economics", Cambridge Journal of Economics, 23: 661-691.

Sayer, L.C., Allison, P.D., England, P., and Kangas, N. (2011) "She left, he left: how employment and satisfaction affect women's and men's decisions to leave marriages", American Journal of Sociology, 116(6): 1982-2018.

Stevenson, B. and Wolfers. J. (2011) "Trust in Public Institutions over the Business Cycle." American Economic Review, 101(3): 281-87.

Wooldridge, J. (2009) "Correlated random effects models with unbalanced panels", Manuscript (version July 2009), Michigan State University. 


$$
\text { Males }
$$

$0.106(0.307)$

$0.108(0.311)$

Parents divorced

Personal

Age

Education: yr 11 and below

Education: yr 12

Education: diploma or certificate

Education: bachelor or honours

Education: postgraduate

Own children 0-14

Stability

Decile 1

Decile 2

Decile 3

Decile 4

Decile 5

Decile 6

Decile 7

Decile 8

Decile 9

Decile 10

$$
\begin{aligned}
& 44.946(17.840) \\
& 0.302(0.459) \\
& 0.137(0.344) \\
& 0.370(0.483) \\
& 0.128(0.334) \\
& 0.092(0.289) \\
& 0.311(0.463) \\
& 10.697(12.024) \\
& 0.090(0.287) \\
& 0.101(0.302) \\
& 0.105(0.307) \\
& 0.094(0.291) \\
& 0.103(0.304) \\
& 0.091(0.288) \\
& 0.098(0.298) \\
& 0.103(0.304) \\
& 0.109(0.312) \\
& 0.112(0.315)
\end{aligned}
$$

\section{Health Conditions}

A nervous or emotional condition

Limited use of feet/legs

Mental illness

Any disfigurement/deformity

\section{Stigma}

Indigenous

Immigrant mother

Immigrant father

Both parents immigrants

\section{Region}

Sydney

Balance of NSW

Melbourne

Balance of Victoria

Brisbane

Balance of QLD

Adelaide

Balance of SA

Perth

Balance of WA

Tasmania

Northern Territory
$0.024(0.152)$

$0.048(0.214)$

$0.009(0.095)$

$0.006(0.077)$

$0.002(0.040)$

$0.323(0.468)$

$0.356(0.479)$

$0.274(0.446)$

$0.160(0.367)$

$0.138(0.345)$

$0.183(0.387)$

$0.075(0.263)$

$0.088(0.283)$

$0.113(0.317)$

$0.060(0.238)$

$0.032(0.177)$

$0.070(0.255)$

$0.029(0.168)$

$0.031(0.173)$

$0.006(0.078)$
$44.340(18.767)$

$0.388(0.487)$

$0.157(0.364)$

$0.239(0.426)$

$0.133(0.339)$

$0.083(0.276)$

$0.341(0.474)$

$10.376(12.081)$

$0.093(0.290)$

$0.109(0.312)$

$0.107(0.310)$

$0.097(0.295)$

$0.097(0.296)$

$0.086(0.281)$

$0.101(0.301)$

$0.103(0.304)$

$0.104(0.305)$

$0.103(0.304)$

$0.035(0.184)$

$0.052(0.221)$

$0.012(0.111)$

$0.005(0.068)$

$0.003(0.052)$

$0.325(0.468)$

$0.355(0.478)$

$0.272(0.445)$

$0.170(0.376)$

$0.136(0.343)$

$0.173(0.378)$

$0.071(0.257)$

$0.094(0.292)$

$0.114(0.317)$

$0.063(0.243)$

$0.030(0.170)$

$0.068(0.252)$

$0.024(0.153)$

$0.032(0.175)$

0.007 (0.082) 
Note: Standard deviation in parentheses. 
Table 2: The effect of parental divorce on generalized trust for women

\section{(1) Ordered probit (2) Random effects (3) Correlated}

ordered probit random effects

ordered probit

Divorced parents

Age

Age squared

Education: yr 12

Education: diploma or certificate

Education: bachelor or honours

Education: postgraduate

Kids 0-14

Stability

Number of siblings

Oldest child

Indigenous

Parents non-Oz

Mom non-Oz

Dad non-Oz

A nervous or emotional condition

Limited use of feet/legs

Mental illness

Any disfigurement or deformity

Mundlak correction

Region

Socio-economic status

Observations

$$
-0.068(0.035) * *
$$

$-0.003(0.003)$

$0.000 \quad(0.000) * * *$

$0.071 \quad(0.034) * *$

$0.029 \quad(0.029)$

$0.189(0.036) * * *$

$0.230 \quad(0.029) * * *$

$-0.013(0.024)$

$0.001 \quad(0.001)$

$-0.012(0.006) * *$

$0.052(0.024)^{* *}$

$0.244 \quad(0.260)$

$-0.063(0.071)$

$-0.107(0.054) * *$

$-0.016(0.042)$

$-0.301(0.061) * * *$

$-0.190(0.050) * * *$

$-0.365(0.104) * * *$

$-0.399(0.151) * * *$

no

yes

yes

14,613
$-0.091(0.045) * *$

$-0.082(0.048) *$

$-0.005(0.004)$

$0.000(0.000) * * *$

$-0.003(0.004)$

$0.000(0.000) * * *$

$0.093(0.041) * *$

$0.124(0.100)$

$0.064(0.036)$ *

$0.516(0.119) * * *$

$0.261(0.045) * * *$

$0.504(0.164) * * *$

$0.423(0.053) * * *$

$0.776(0.216) * * *$

$-0.015(0.029)$

$-0.071(0.055)$

$0.002(0.001)$

$0.002(0.001)$

$-0.018(0.007) * *$

$-0.017(0.007) * *$

$0.062(0.0309) * *$

$0.059(0.031) *$

$0.319 \quad(0.281)$

$-0.100(0.087)$

$0.304(0.281)$

$-0.098(0.087)$

$-0.118(0.066) *$

$-0.123(0.066) *$

$-0.018(0.053)$

$-0.013(0.053)$

$-0.239(0.065) * * *$

$0.057(0.083)$

$-0.188(0.054) * * *$

$-0.048(0.070)$

$-0.455(0.111) * * *$

$-0.242(0.168)$

$-0.305(0.146) * *$

$0.096(0.200)$

yes

yes

yes

14,613

14,613

The dependent variable is a 7-point Likert scale composed of slightly/moderately/strongly agreeing or disagreeing (with 4 being neutral) with the statement: "Generally speaking, most people can be trusted". The coefficient estimates for the socio-economic status and region are not reported but are available on request.

Standard errors are in parentheses. Standard errors are clustered for ordered probit model (1). Coefficient significance levels are denoted by $*(10 \%), * *(5 \%)$, and $* * *(1 \%)$. 
Table 3: The effect of parental divorce on generalized trust for men

\section{(1) Ordered probit (2) Random effects (3) Correlated ordered probit random effects ordered probit}

Divorced parents

Age

Age squared

Education: yr 12

Education: diploma or certificate

Education: bachelor or honours

Education: postgraduate

Kids 0-14

Stability

Number of siblings

Oldest child

Indigenous

Parents non-Oz

Mom non-Oz

Dad non-Oz

A nervous or emotional condition

Limited use of feet/legs

Mental illness

Any disfigurement or deformity

Mundlak correction

Region

Socio-economic status

Observations

\begin{tabular}{|c|c|c|c|c|}
\hline-0.083 & $(0.039) * *$ & $\begin{array}{l}-0.102 \\
-0.013\end{array}$ & $\begin{array}{l}(0.048) * * \\
(0.004) * * *\end{array}$ & $\begin{array}{l}-0.097(0.048) * * \\
-0.013(0.004) * * *\end{array}$ \\
\hline-0.009 & $(0.004) * *$ & 0.000 & $(0.000) * * *$ & \\
\hline 0.000 & $(0.000) * * *$ & 0.042 & $(0.047)$ & $0.000(0.000) * * *$ \\
\hline 0.021 & $(0.038)$ & -0.027 & $(0.038)$ & $0.220(0.104) * *$ \\
\hline .031 & $(0.031)$ & 0.026 & $(0.052) * * *$ & $0.303(0.138) * *$ \\
\hline 0.189 & $(0.042) * * *$ & 0.268 & $(0.061) * * *$ & $0.664(0.197) * * *$ \\
\hline 0.188 & $(0.048) * * *$ & -0.009 & $(0.030)$ & $0.855(0.267) * * *$ \\
\hline-0.007 & $(0.025)$ & 0.005 & $(0.001) * * *$ & $-0.081(0.055)$ \\
\hline 0.005 & $(0.001) * * *$ & 0.009 & $(0.008)$ & $0.005(0.001) * * *$ \\
\hline 0.009 & $(0.007)$ & 0.048 & $(0.033)$ & $0.009(0.008)$ \\
\hline 0.034 & $(0.025)$ & -0.316 & $(0.279)$ & $0.046(0.033)$ \\
\hline-0.225 & $(0.257)$ & -0.053 & $(0.092)$ & $-0.299(0.280)$ \\
\hline-0.025 & $(0.070)$ & -0.129 & $(0.070) *$ & $-0.054(0.092)$ \\
\hline-0.102 & $(0.052) *$ & -0.035 & $(0.055)$ & $-0.126(0.070) *$ \\
\hline-0.034 & $(0.043)$ & -0.510 & $(0.084) * * *$ & $-0.034(0.055)$ \\
\hline-0.45 & $(0.075) *$ & -0.129 & $(0.059) * *$ & \\
\hline & & & & $-0.378(0.111) * * *$ \\
\hline & $(0.057) * *$ & -0.007 & $(0.129)$ & $0.036(0.077)$ \\
\hline & & -0.045 & $(0.158)$ & $0.223(0.165)$ \\
\hline & & & & $0.054(0.199)$ \\
\hline
\end{tabular}

no
yes
yes

no

yes

yes

yes

The dependent variable is a 7-point Likert scale composed of slightly/moderately/strongly agreeing or disagreeing (with 4 being neutral) with the statement: "Generally speaking, most people can be trusted". The coefficient estimates for the socio-economic status and region are not reported but are available on request.

Standard errors are in parentheses. Standard errors are clustered for ordered probit model (1). Coefficient significance levels are denoted by $*(10 \%), * *(5 \%)$, and $* * *(1 \%)$. 
Table 4: Instrumental variables estimates on the effect of parental divorce on generalized trust

\begin{tabular}{|c|c|c|c|c|}
\hline & \multicolumn{2}{|c|}{ WOMEN } & \multicolumn{2}{|c|}{ MEN } \\
\hline & $\begin{array}{c}(1) \\
\text { Instruments: } \\
\text { law changes }+ \\
\text { parental } \\
\text { background }\end{array}$ & $\begin{array}{l}\quad(2) \\
\text { Instruments: } \\
\text { law changes }\end{array}$ & $\begin{array}{c}(3) \\
\text { Instruments: } \\
\text { law changes }+ \\
\text { parental } \\
\text { background }\end{array}$ & $\begin{array}{l}\quad(4) \\
\text { Instruments } \\
\text { law change }\end{array}$ \\
\hline Divorced parents & $\begin{array}{l}-0.044 * * * \\
(0.013)\end{array}$ & $\begin{array}{l}-0.022 * * \\
(0.009)\end{array}$ & $\begin{array}{l}-0.097 * * * \\
(0.014)\end{array}$ & $\begin{array}{l}-0.075 * * * \\
(0.011)\end{array}$ \\
\hline Age & $\begin{array}{l}-0.003 \\
(0.002)\end{array}$ & $\begin{array}{l}-0.003 \\
(0.002)\end{array}$ & $\begin{array}{l}-0.009 * * * \\
(0.003)\end{array}$ & $\begin{array}{l}-0.009 * * * \\
(0.003)\end{array}$ \\
\hline Age squared & $\begin{array}{l}0.000 * * * \\
(0.000)\end{array}$ & $\begin{array}{l}0.000 * * * \\
(0.000)\end{array}$ & $\begin{array}{l}0.000 * * * \\
(0.000)\end{array}$ & $\begin{array}{l}0.000 * * * \\
(0.000)\end{array}$ \\
\hline Education: yr 12 & $\begin{array}{l}0.0707 * * * \\
(0.026)\end{array}$ & $\begin{array}{l}0.071 * * * \\
(0.026)\end{array}$ & $\begin{array}{l}0.021 \\
(0.029)\end{array}$ & $\begin{array}{l}0.021 \\
(0.029)\end{array}$ \\
\hline $\begin{array}{l}\text { Education: diploma or } \\
\text { certificate }\end{array}$ & $\begin{array}{l}0.029 \\
(0.021)\end{array}$ & $\begin{array}{l}0.029 \\
(0.021)\end{array}$ & $\begin{array}{l}-0.031 \\
(0.024)\end{array}$ & $\begin{array}{l}-0.031 \\
(0.024)\end{array}$ \\
\hline $\begin{array}{l}\text { Education: bachelor } \\
\text { or honours }\end{array}$ & $\begin{array}{l}0.189 * * * \\
(0.026)\end{array}$ & $\begin{array}{l}0.189 * * * \\
(0.026)\end{array}$ & $\begin{array}{l}0.189 * * * \\
(0.031)\end{array}$ & $\begin{array}{l}0.189 * * * \\
(0.031)\end{array}$ \\
\hline $\begin{array}{l}\text { Education: } \\
\text { postgraduate }\end{array}$ & $\begin{array}{l}0.299 * * * \\
(0.031)\end{array}$ & $\begin{array}{l}0.299 * * * \\
(0.031)\end{array}$ & $\begin{array}{l}0.188 * * * \\
(0.035)\end{array}$ & $\begin{array}{l}0.188 * * * \\
(0.035)\end{array}$ \\
\hline Kids $0-14$ & $\begin{array}{l}-0.013 \\
(0.018)\end{array}$ & $\begin{array}{l}-0.014 \\
(0.018)\end{array}$ & $\begin{array}{l}-0.006 \\
(0.019)\end{array}$ & $\begin{array}{l}-0.007 \\
(0.019)\end{array}$ \\
\hline Stability & $\begin{array}{l}0.002 * \\
(0.001)\end{array}$ & $\begin{array}{l}0.001 * \\
(0.001)\end{array}$ & $\begin{array}{l}0.005 * * * \\
(0.001)\end{array}$ & $\begin{array}{l}0.005 * * * \\
(0.001)\end{array}$ \\
\hline Number of siblings & $\begin{array}{l}-0.012 * * * \\
(0.004)\end{array}$ & $\begin{array}{l}-0.012 * * * \\
(0.004)\end{array}$ & $\begin{array}{l}0.009 * \\
(0.005)\end{array}$ & $\begin{array}{l}0.009 * \\
(0.005)\end{array}$ \\
\hline Oldest child & $\begin{array}{l}0.052 * * * \\
(0.018)\end{array}$ & $\begin{array}{l}0.052 * * * \\
(0.018)\end{array}$ & $\begin{array}{l}0.033 * \\
(0.019)\end{array}$ & $\begin{array}{l}0.034 * \\
(0.019)\end{array}$ \\
\hline Indigenous & $\begin{array}{l}0.242 \\
(0.156)\end{array}$ & $\begin{array}{l}0.240 \\
(0.156)\end{array}$ & $\begin{array}{l}-0.225 \\
(0.207)\end{array}$ & $\begin{array}{l}-0.226 \\
(0.207)\end{array}$ \\
\hline Parents non-Oz & $\begin{array}{l}-0.063 \\
(0.052)\end{array}$ & $\begin{array}{l}-0.063 \\
(0.052)\end{array}$ & $\begin{array}{l}-0.025 \\
(0.052)\end{array}$ & $\begin{array}{l}-0.025 \\
(0.052)\end{array}$ \\
\hline Mom non-Oz & $\begin{array}{l}-0.107 * * * \\
(0.038)\end{array}$ & $\begin{array}{l}-0.107 * * * \\
(0.038)\end{array}$ & $\begin{array}{l}-0.102 * * * \\
(0.039)\end{array}$ & $\begin{array}{l}-0.102 * * * \\
(0.039)\end{array}$ \\
\hline Dad non-Oz & $\begin{array}{l}-0.016 \\
(0.032)\end{array}$ & $\begin{array}{l}-0.016 \\
(0.032)\end{array}$ & $\begin{array}{l}-0.034 \\
(0.032)\end{array}$ & $\begin{array}{l}-0.034 \\
(0.032)\end{array}$ \\
\hline $\begin{array}{l}\text { A nervous or } \\
\text { emotional condition }\end{array}$ & $\begin{array}{l}-0.301 * * * \\
(0.047)\end{array}$ & $\begin{array}{l}-0.301 * * * \\
(0.047)\end{array}$ & $\begin{array}{l}-0.452 * * * \\
(0.064)\end{array}$ & $\begin{array}{l}-0.452 * * * \\
(0.064)\end{array}$ \\
\hline $\begin{array}{l}\text { Limited use of } \\
\text { feet/legs }\end{array}$ & $\begin{array}{l}-0.190 * * * \\
(0.039)\end{array}$ & $\begin{array}{l}-0.190 * * * \\
(0.039)\end{array}$ & $\begin{array}{l}-0.130 * * * \\
(0.043)\end{array}$ & $\begin{array}{l}-0.129 * * * \\
(0.043)\end{array}$ \\
\hline Mental illness & $\begin{array}{l}-0.365 * * * \\
(0.0812)\end{array}$ & $\begin{array}{l}-0.365 * * * \\
(0.081)\end{array}$ & $\begin{array}{l}-0.041 \\
(0.108)\end{array}$ & $\begin{array}{l}-0.042 \\
(0.109)\end{array}$ \\
\hline $\begin{array}{l}\text { Any disfigurement or } \\
\text { deformity }\end{array}$ & $\begin{array}{l}-0.400 * * * \\
(0.097)\end{array}$ & $\begin{array}{l}-0.400 * * * \\
(0.097)\end{array}$ & $\begin{array}{l}-0.044 \\
(0.104)\end{array}$ & $\begin{array}{l}-0.044 \\
(0.104)\end{array}$ \\
\hline Region & yes & yes & yes & Yes \\
\hline
\end{tabular}




$\begin{array}{lllll}\text { Socio-economic status } & \text { yes } & \text { yes } & \text { yes } & \text { yes } \\ \text { First stage instruments } & & & & \\ \text { Pre-uniform } & -0.078 * * * & -0.081 * * * & -0.077 * * * & -0.076 * * * \\ & (0.011) & (0.011) & (0.012) & (0.012) \\ \text { No fault } & -0.018 & -0.054 * * * & -0.025 & -0.049 * * * \\ & (0.015) & (0.013) & (0.017) & (0.014) \\ \text { Easy divorce } & 0.031 * & & -0.005 & \\ \text { background } & (0.019) & & (0.016) & \\ \text { Dad unemployed at } & 0.070 * * * & & 0.082 * * * & \\ \text { 14 } & (0.016) & & (0.018) & \\ \text { Still at home } & -0.088 * * * & & -0.058 * * * & \\ & (0.014) & & (0.016) & \\ \text { Observations } & 14,613 & 14,613 & 12,869 & 12,869\end{array}$

The dependent variable is a 7-point Likert scale composed of slightly/moderately/strongly agreeing or disagreeing (with 4 being neutral) with the statement: "Generally speaking, most people can be trusted". The coefficient estimates for the socio-economic status and region are not reported but are available on request.

Standard errors are in parentheses. Coefficient significance levels are denoted by $*(10 \%),{ }^{* *}$ $(5 \%)$, and $* * *(1 \%)$. 
Table 5: The effect of age at parental divorce on generalized trust excluding the pre-uniform law era: instrumental variables models

\begin{tabular}{|c|c|c|c|c|}
\hline & \multicolumn{2}{|c|}{ WOMEN } & \multicolumn{2}{|c|}{ MEN } \\
\hline & $\begin{array}{c}(1) \\
\text { Instruments: } \\
\text { law changes }+ \\
\text { parental } \\
\text { background }\end{array}$ & $\begin{array}{l}\text { (2) } \\
\text { Instruments: } \\
\text { law changes }\end{array}$ & $\begin{array}{c}(3) \\
\text { Instruments: } \\
\text { law changes }+ \\
\text { parental } \\
\text { background }\end{array}$ & $\begin{array}{l}\text { (4) } \\
\text { Instruments: } \\
\text { law changes }\end{array}$ \\
\hline Age $0-4$ years & $\begin{array}{l}-0.625 * \\
(0.347)\end{array}$ & $\begin{array}{l}-0.576 * \\
(0.348)\end{array}$ & $\begin{array}{l}-0.186 \\
(0.440)\end{array}$ & $\begin{array}{l}-0.208 \\
(0.409)\end{array}$ \\
\hline Age 5-12 years & $\begin{array}{l}-0.309 \\
(0.232)\end{array}$ & $\begin{array}{l}-0.282 \\
(0.230)\end{array}$ & $\begin{array}{l}-0.267 \\
(0.293)\end{array}$ & $\begin{array}{l}-0.280 \\
(0.277)\end{array}$ \\
\hline Age $13-17$ years & $\begin{array}{l}-0.188 \\
(0.145)\end{array}$ & $\begin{array}{l}-0.170 \\
(0.143)\end{array}$ & $\begin{array}{l}-0.201 \\
(0.167)\end{array}$ & $\begin{array}{l}-0.205 \\
(0.158)\end{array}$ \\
\hline Individual controls & yes & yes & yes & yes \\
\hline Region & yes & yes & yes & yes \\
\hline Socio-economic status & yes & yes & yes & yes \\
\hline First stage instruments & & & & \\
\hline No fault & $\begin{array}{l}-4.133 * * * \\
(0.753)\end{array}$ & $\begin{array}{l}-4.805 * * * \\
(0.697)\end{array}$ & $\begin{array}{l}-3.235 * * * \\
(0.723)\end{array}$ & $\begin{array}{l}-3.598 * * * \\
(0.670)\end{array}$ \\
\hline $\begin{array}{l}\text { Easy divorce } \\
\text { background }\end{array}$ & $\begin{array}{l}0.870 \\
(1.143)\end{array}$ & & $\begin{array}{l}-1.379 \\
(1.534)\end{array}$ & \\
\hline $\begin{array}{l}\text { Dad unemployed at } \\
14 \\
\text { Still at home }\end{array}$ & $\begin{array}{l}-1.280 \\
(0.942) \\
-3.038 * * * \\
(1.085)\end{array}$ & & $\begin{array}{l}-0.913 \\
(0.941) \\
-1.548 * \\
(0.874)\end{array}$ & \\
\hline Observations & 667 & 667 & 563 & 563 \\
\hline
\end{tabular}

The dependent variable is a 7-point Likert scale composed of slightly/moderately/strongly agreeing or disagreeing (with 4 being neutral) with the statement: "Generally speaking, most people can be trusted". The coefficient estimates for the individual controls are not reported but are available on request.

Standard errors are in parentheses. Coefficient significance levels are denoted by * $(10 \%)$, ** $(5 \%)$, and *** (1\%). 
Figure 1: Crude divorce rates (divorces per 1,000 population), states and territories, 19012006



$\begin{array}{ll}\text { New South Wales } & \text { Victoria } \\ \text { South Australia } & \text { Queensland } \\ \text { Northern Territory } & \text { Australia }\end{array}$

Source: Australian Bureau of Statistics 